\title{
"A Great Victory": Abraham Flexner and the New Medical Campus at the University of Iowa
}

\section{LEE ANDERSON}

THREE DAYS OF CEREMONIES in November 1928 marked the completion of the new University of Iowa medical campus on the west bank of the Iowa River. The new facilities were impressive in both size and cost; their construction had required more than four years and $\$ 4.5$ million, half of that sum provided by Iowa taxpayers and half by the Rockefeller Foundation and the General Education Board. The expanded facilities vaulted the university to a place in the top rank of America's medical schools. Thus, the November celebration attracted many of the leading figures in American medical education, including James B. Herrick of the University of Chicago, George $\mathrm{H}$. Whipple of the University of Rochester, Hugh Cabot of the University of Michigan, G. Canby Robinson of Cornell University, and William J. Mayo of the Mayo Clinic. Ironically, however, the man perhaps most responsible for the new complex was conspicuously absent. That man was Abraham Flexner.

Flexner had first achieved prominence with the publication of his Medical Education in the United States and Canada (1910), a critical survey conducted under the auspices of the Carnegie Foundation for the Advancement of Teaching. ${ }^{1}$ While

1. Abraham Flexner, Medical Education in the United States and Canada (New York, 1910). Flexner's study is as controversial today as it was in 1910; see, for example, Thomas N. Bonner, "Abraham Flexner and the Historians," Journal of the History of Medicine and Allied Sciences 45 (1990), 3-10.

THE ANNALS OF IOWA 51 (Winter 1992). (CThe State Historical Society of Iowa, 1992. 
preparing that work, Flexner had visited the University of Iowa College of Medicine twice in 1909, and his report to university president George E. MacLean was a scathing indictment of Iowa's clinical facilities, faculty, and teaching methods. ${ }^{2}$ Flexner's conclusion that Iowa medical students might be better served in Minneapolis or Chicago than in such a "small inland residential community" had triggered a desperate effort by the university administration and the state board of education to save the College of Medicine. ${ }^{3}$

Flexner's turn from critic to champion of the University of Iowa College of Medicine and the college's rise from rags to riches are of more than dramatic interest. First, the emergence of a major medical center from the lowa cornfields was vivid testimony to Abraham Flexner's lasting imprint on American medical education beyond the world of Johns Hopkins, Yale, or Columbia. ${ }^{4}$ Second, Flexner's unexpected endorsement of the Iowa project was part of a distinct change in policy for the Rockefeller philanthropies; both the Rockefeller Foundation and the General Education Board had invested large sums in private medical schools between 1910 and 1920, but the University of lowa was the first public institution to receive their largess. Third, the mingling of Rockefeller money with state matching funds brought to the fore questions of the increasing influence of outside forces on medical education in Iowa and, at a broader level, the acceptable limits of interaction between private and public institutions. Finally, the stately north tower of the new general hospital, "a distinctive landmark for the city and surrounding country," ${ }^{25}$ proved symbolic of a new public confidence in the University of Iowa and

2. See Stow Persons, "The Flexner Investigation of the University of Iowa Medical School," Annals of lowa 48 (1986), 274-91.

3. Abraham Flexner, "State University of Iowa. Medical Department," box 25, file 5, George E. MacLean Papers, University of Iowa Archives, Iowa City.

4. For a general discussion of Flexner and the role of philanthropic foundations in the development of medical education, see Stephen C. Wheatley, The Politics of Philanthropy: Abraham Flexner and Medical Education (Madison, WI, 1988).

5. From the dedicatory program prepared in November 1928, Department of Internal Medicine Collections, University of Iowa. 
in the power of medical science to conquer the challenge of illness and death.

ABRAHAM FLEXNER'S 1909 REPORT on the University of Iowa College of Medicine, harsh though it was, had provided openings for the salvage effort spearheaded by President George E. MacLean and William R. Boyd, a Cedar Rapids newspaperman and longtime chairman of the Finance Committee of the lowa State Board of Education. For example, although Flexner had charged that the Iowa City community was too small to furnish sufficient material for clinical instruction, he had conceded that a first-rate care facility would "probably draw to Iowa City all the clinical material that is needed." Similarly, while he had derided the "antiquated methods of teaching" in clinical programs conducted "on a high school basis," he had noted that clinical instruction could "be improved without any greater expenditure than is involved in securing a permanent resident dean, a permanent resident surgeon, and a hospital head." 6

The concerted efforts of Boyd and MacLean to answer Flexner's charges led to an accelerated commitment of state funds to the College of Medicine. As a result, the medical campus grew rapidly between 1910 and 1920 . At the same time, increased salaries and nationwide recruitment efforts brought prominent faculty to the college, beginning with the recruitment in 1910 of Campbell Palmer Howard-a protégé of William Osler-from McGill University in Montreal to head the Department of Theory and Practice of Medicine. Thus, by 1920 the University of Iowa College of Medicine was firmly integrated into the increasingly sophisticated world of medical science and education. In addition, thanks to both its expanding physical plant and its growing scientific reputation, the college had become a regular stop for touring dignitaries, foreign and domestic, many of them sponsored by the Rockefeller Foundation.

Given the rapid pace of expansion in the wake of Abraham Flexner's investigation, the three-square-block medical campus between Gilbert and Clinton streets on Iowa Avenue became increasingly cramped, so in 1917 a faculty committee unveiled

6. Flexner, "State University of Iowa. Medical Department." 
an ambitious plan "for an entire group of hospital and medical buildings" on a 58-acre tract on the west bank of the Iowa River. ${ }^{7}$ The centerpiece of the plan was a spacious thousandbed general hospital supported by a children's hospital, a psychiatric hospital, a medical laboratories building, and a nurses' dormitory. The proposed new facilities, with some five times as many patient beds as the old buildings, would not only supply additional clinical material and support services for medical instruction, but would also broaden the University Hospitals' political base by accommodating more indigent patients from across the state. All of this growth promised to make the University Hospitals the capstone of a "state hospital service" - the origin of today's "tertiary care facility."

The proposal to make the University Hospitals a center for indigent health care was not a new idea. Although a similar proposal had surfaced in the late nineteenth century, the idea began to be implemented only in 1914 with a medical faculty proposal to bring "crippled and afflicted" children to the university at public expense. ${ }^{8}$ The following year, acting on the recommendation of the state board of education, the Iowa General Assembly passed the Perkins Law, named for its sponsor, Senator Eli C. Perkins. That law allowed each of Iowa's counties access to university facilities for the care of indigent children and of adults held in state institutions. The Thirty-eighth General Assembly of 1919 broadened access to indigent health care through the Haskell-Klaus Law, which designated the University Hospitals as a referral center for all indigent adults.

Many so-called Haskell-Klaus and Perkins patients benefited from complicated orthopedic procedures. This provided a publicity windfall and made indigent patient care big business at the University of Iowa Hospitals. By the 1920-21 fiscal year, state payments for care of both adults and children surpassed a half-million dollars. ${ }^{9}$ Indigent adult admissions alone totaled more than three thousand, and patient waiting lists for the vari-

7. Medical Faculty Minutes, 19 April 1917, University of Iowa Archives.

8. Lee W. Dean to Thomas H. Macbride, 26 October 1914, file 6, 1914, Thomas H. Macbride Papers, University of lowa Archives.

9. Walter A. Jessup to Norman Walker, 26 July 1921, file 1(f), 1921-22, Walter A. Jessup Papers, University of Iowa Archives. 
ous medical and surgical services mushroomed into the hundreds. Along with burgeoning medical school enrollments, the substantially increased patient load at the hospitals and the lengthy waiting lists for all hospital services were significant factors in the campaign for the new medical complex.

MEANWHILE, after completing his study of American and European medical education for the Carnegie Foundation, Abraham Flexner went on to investigate European prostitution for the Rockefeller Foundation. Then in 1912 he became an assistant to General Education Board Secretary Wallace Buttrick, and in 1914 he also became a trustee of the General Education Board (GEB). Since its organization by John D. Rockefeller in 1902, the GEB had been involved in a variety of educational projects. After 1912, bolstered by a significantly enlarged endowment, the board increasingly focused its energies on the reform of medical education. In the process, it became an instrument by which Abraham Flexner extended his influence in that rapidly expanding field.

In the next few years, the GEB invested tens of millions of dollars in medical schools at prestigious private institutions such as Johns Hopkins, Washington University, Columbia, and Chicago. These subsidies of the implementation of modern scientific medical education included the realization of Flexner's ideal of full-time clinical faculty. By 1920, in the wake of what Steven Wheatley has called an eight-year "organizational whirlwind," both the GEB and the Rockefeller Foundation stood at a crossroads. ${ }^{10}$ Their trustees-aside from Abraham Flexner-were uncertain over the best way to apply the Rockefeller millions earmarked for support of medical education. The Rockefeller agencies, after all, could not afford to underwrite all of America's private medical schools. Moreover, support for private schools had done little to improve the quality of education at America's more numerous public medical schools.

The highly publicized link between philanthropy and medical education in the decade prior to 1920 led William $R$. Boyd and other officials at the University of Iowa to seek phil-

10. Wheatley, The Politics of Philanthropy, 86. 
anthropic support for their new medical campus. ${ }^{11}$ At about the same time, Abraham Flexner was toying with the idea of offering Rockefeller support to public institutions. Although such a plan would represent a new departure, it was nonetheless consistent with the trend toward collaboration between public and private institutions begun during World War I and carried over into the 1920 s by such prominent figures as Herbert Hoover. ${ }^{12}$

In 1921 the Iowa State Board of Education issued a formal declaration of purpose for the medical college. The report noted that because of the rising demand for both medical education and patient care at the university, "an entirely new medical group must of necessity be established."13 By that time, Abraham Flexner's interest in the college had reawakened, and Flexner soon emerged as the University of Iowa's chief advocate within key philanthropic circles in New York. ${ }^{14}$

In Flexner's telling, it was largely his warm regard for William Boyd that kindled his intense interest and involvement in the Iowa project. Flexner had visited the University of Iowa campus in early December 1920. That visit came on the heels of an East Coast meeting with University of Iowa President Walter A. Jessup, whom Flexner described as "a perfectly corking fellow, solid, hard headed."15 A few days after his campus visit Flexner wrote to Lee Wallace Dean, who was dean of the College of Medicine, asking for further details of the proposed building plan. ${ }^{16}$

Flexner later recalled that William Boyd then appeared in New York to describe the plan in person. Although Flexner was generally enthusiastic about the project Boyd outlined, he

11. The idea to seek such support was credited to Boyd by Stow Persons, The University of Iowa in the Twentieth Century: An Institutional History (Iowa City, 1990), 221.

12. See Ellis W. Hawley, The Great War and the Search for a Modern Order: $A$ History of the American People and Their Institutions, 1917-1933 (New York, 1979).

13. File 1(c), 1920-21, Jessup Papers.

14. See, for example, Flexner's letter to Dean Lee W. Dean, 12 February 1920, file 1(a), 1919-20, Jessup Papers.

15. Quoted in Wheatley, The Politics of Philanthropy, 101.

16. See file 1(a), 1920-21; Jessup to Flexner, 30 August 1920; Dean to Jessup, 11 December 1920, file 1, 1920-21, Jessup Papers. 
objected to the piecemeal approach that would stretch construction into the unforeseeable future. "By the time the plant and reorganization were completed," he later noted, "we should all be dead and gone." After a hasty consultation with President George E. Vincent of the Rockefeller Foundation and Secretary Buttrick of the GEB, Flexner instead proposed to Boyd a plan "to put the entire reorganization through at once," with the Rockefeller Foundation and GEB together providing half of the estimated cost of $\$ 4.5$ million. ${ }^{17}$

Flexner's memory of events was at the very least somewhat streamlined. First, he appears to have telescoped two or more meetings with Boyd, and perhaps with other university representatives as well, into a single account; at any rate, it is impossible to say which of several meetings Flexner was describing. More important, Flexner's influence over the distribution of Rockefeller funds was not so certain as he later remembered, particularly in light of the fact that the Iowa project represented a departure into the funding of public institutions. As a result, frustrating delays repeatedly stalled his plan for the University of Iowa and at times threatened to undermine it altogether.

In addition, Flexner neglected to mention in his account that he initially envisioned the Carnegie Corporation as an equal partner with the Rockefeller philanthropies in financing the lowa project. Two facts boosted Flexner's hopes for the Carnegie Corporation's participation. First, his old Carnegie Foundation boss, Henry S. Pritchett, was then head of the corporation. Second, it was reasonable to suppose that the Carnegie Corporation might be preparing to reduce its commitment to financing public libraries and church organs and to strike out in new directions in the wake of Andrew Carnegie's death in $1919 .{ }^{18}$

Flexner was also unclear in stating his motivation for supporting the University of Iowa's request. No doubt his personal relationship with William Boyd was, as both men claimed,

17. Abraham Flexner, I Remember (New York, 1940), 292-93.

18. For a history of the Carnegie Corporation, see Ellen Condliffe Lagemann, The Politics of Knowledge: The Carnegie Corporation, Philanthropy, and Public Policy (Middletown, CT, 1989). 
important for securing Flexner's interest in the University of Iowa, but that relationship, by Flexner's own recollection, was an effect rather than a cause of his meetings with Boyd in the early 1920s. No doubt, too, as Flexner claimed, he saw the need for a second tier of medical schools, necessarily at public universities, where teachers trained at elite institutions could find employment and spread the gospel of scientific medical education. ${ }^{19}$ However, it was also true that Flexner was having second thoughts about the dominant position of elite eastern schools in American medical education, a circumstance that he had done much to promote. In a letter to President Jessup in 1922, for example, Flexner expressed his regret that "leadership in medical education in this country has lain with endowed institutions." The Iowa project, he noted, would help to redress that imbalance. ${ }^{20}$ Diminishing the power of the elite eastern schools would also help to cement his own position of leadership in American medical education.

From the first, Abraham Flexner was positive that he could win approval from the Rockefeller trustees, although he may well have had his doubts about the Carnegie Corporation board. Based on Flexner's reassurances, William Boyd was optimistic in early 1921. "I believe these people are going to do something worthwhile for us," Boyd wrote to President Jessup. But events proceeded much more slowly than Flexner had led Boyd to expect. Dean Lee W. Dean of the College of Medicine met with the "Rockefeller people" in New York in May 1921. On May 25 Flexner assured President Jessup that he would "bring the matter to Dr. Buttrick's attention just as soon as I have opportunity enough to go into it thoroughly with him." Three days later the lowa State Board of Education submitted its formal request to the GEB. At that time Jessup wrote to Flexner, ${ }^{\prime \prime}$ We are awaiting the final decision of your board with the keenest expectancy." In early June, however, the word from Flexner was discouraging. It was "impossible to take up your applica-

19. Wheatley, The Politics of Philanthropy, 99-100. Ironically, one of the criticisms of Flexner's 1910 report was that it was a transparent attempt to create opportunities for unemployed and underemployed Johns Hopkins graduates.

20. Flexner to Jessup, 27 November 1922, file 1, 1922-23, Jessup Papers. 
tion with Dr. Buttrick at this time," he wrote. However, Flexner continued, "I hope in the fall to go over the matter with him. ${ }^{.21}$

Six months later, in December 1921, Boyd met with Flexner again, but still no firm commitment materialized from any of the promised sources. Finally, in May 1922, after yet another meeting with Flexner, Boyd assured President Jessup that the details were "all arranged." The GEB, the Rockefeller Foundation, and the Carnegie Corporation, Boyd reported, would each provide one-sixth of the total cost of $\$ 4.5$ million contingent upon the Iowa legislature's pledging matching funds of $\$ 2.25$ million. ${ }^{22}$

On May 24, 1922, as Flexner promised, the executive committee of the Rockefeller Foundation formalized its pledge of $\$ 750,000$, conditioned on a similar commitment from the GEB. Two days later, however, Flexner notified President Jessup that because of a crowded agenda the GEB had not made a final decision during its May meeting. Flexner promised that the GEB trustees would discuss the lowa proposal at a special meeting in the autumn. ${ }^{23}$ The GEB's agenda for that May meeting may indeed have been as crowded as Flexner claimed, but the real obstacle to the Iowa proposal was the vehement opposition of Frederick T. Gates. Gates was John D. Rockefeller's longtime philanthropic adviser and GEB chairman from 1907 to 1917. He maintained a strict division between public and private spheres. He saw no future in investing money in the University of Iowa in particular and argued in general that if a public university needed money, the taxpayers should provide it.

From late spring to early fall of 1922, the University of Iowa's once bright prospects grew dim. The Rockefeller Foundation was on board, and Foundation President George Vincent visited the Iowa campus in August, but a matching commitment from the GEB no longer seemed a sure thing, Flexner's assurance and support notwithstanding. Moreover,

21. Boyd to Jessup, 20 April 1921; Flexner to Jessup, 25 May 1921; W. H. Gemmill and W. R. Boyd to Flexner, 28 May 1921; Jessup to Flexner, 2 June 1921; Flexner to Jessup, 7 June 1921, file 1, 1920-21, Jessup Papers.

22. Boyd to Jessup, 13 May 1922, file 1(f), 1921-22, Jessup Papers.

23. Flexner to Jessup, 26 May and 7 June 1922, file 1, 1921-22, Jessup Papers. 
after a long silence, Henry S. Pritchett of the Carnegie Corporation reminded President Jessup in late October that Carnegie's policy was "not to make grants to tax-supported institutions." A few days later Pritchett wrote again, this time warning darkly, "I think it unlikely ... that the Carnegie Corporation will be able to make this appropriation." Pritchett's prediction proved correct. The most likely immediate reason was, as Pritchett explained, the corporation's heavy commitments elsewhere. ${ }^{24}$

Flexner appears not to have been at all surprised by the Carnegie Corporation's withdrawal; he may have seen the corporation's participation as a long shot from the beginning. Two days before Pritchett's warning, Flexner had asked President Jessup what plan he would expect to pursue if the Carnegie Corporation did not make the appropriation requested. Jessup could only respond weakly, "We have not even considered any other outcome." If the Carnegie people did not come through, he said in despair, it "would probably make our whole program impossible." 25

In the meantime, however, Flexner had, as promised, carried the Iowa case before the trustees of the GEB at a special October meeting. As expected, Frederick Gates made a lengthy and impassioned plea in which, in Flexner's words, he "tore the whole proposition to pieces." Gates not only reiterated his philosophical objection to the joining of private philanthropy and public institutions; he was also less than impressed with the potential of the University of Iowa College of Medicine. To speculate that the college could become a school of national prominence, Gates maintained, "is to take a gambler's chance with our money." Flexner argued that the proposed gift to the University of Iowa would not only make Iowa a first-rank school, but would, out of "friendly rivalry," spark similar improvements at other midwestern schools at no expense to the GEB. ${ }^{26}$

24. Pritchett to Jessup, 31 October and 8 November 1922, file 1, 1922-23, Jessup Papers; Wheatley, The Politics of Philanthropy, 105.

25. Flexner to Jessup, 6 November 1922; Jessup to Flexner, 9 November 1922, file 1, 1922-23, Jessup Papers.

26. Flexner, I Remember, 294, 296; Gates quoted in Wheatley, The Politics of Philanthropy, 103. 
Gates and Flexner were easily the dominant personalities on the board, and each was accustomed to having his way in the governance of the GEB. Although they had worked more or less in concert toward shared goals in the previous decade, Gates's unyielding philosophical objections on this occasion split them apart. The trustees' subsequent formal endorsement in principle of Flexner's position was a resounding victory for Flexner, a shattering defeat for Gates, and a pivotal moment in the history of the GEB. However, it is one of the many ironies of the story that Flexner's victory displayed precisely the kind of ad hoc institution-building and personalized management that within a few years would prompt a major restructuring of the Rockefeller philanthropies and their goals. ${ }^{27}$

Buoyed by his success with the GEB and undaunted by the Carnegie setback, Flexner was as determined as ever in early November, when he assured Iowa officials that "we shall sink or swim together. ${ }^{28}$ In fact, Flexner had already hatched an alternative scheme calling for the Rockefeller Foundation and the GEB to shoulder the full $\$ 2.25$ million by themselves. Flexner advised the Iowa State Board of Education to prepare another detailed request for assistance, reiterating both the need for and the benefits of the new hospitals complex. On November 9 the board submitted its final draft, along with a personal note from Iowa Governor Nathan Kendall, to both the GEB and the Foundation. ${ }^{29}$

At long last, all of the pieces fell into place just as Flexner had promised nearly two years earlier. In a telegram dated November 23, 1922, Flexner notified President Jessup confidentially that the GEB was prepared to raise its contribution to one-fourth of the $\$ 4.5$ million. The next day Flexner mailed formal notification of the gift to the secretary of the Iowa State Board of Education. Still, the Rockefeller Foundation trustees had not yet decided whether to commit an additional $\$ 375,000$. President Jessup-obviously and understandably on pins and needles-pestered Flexner for news on that front. Finally, on December 7, the Rockefeller Foundation trustees approved a

27. See Wheatley, The Politics of Philanthropy, 140-66.

28. Quoted in Wheatley, The Politics of Philanthropy, 105.

29. File 1, 1922-23, Jessup Papers. 
matching gift of $\$ 1,125,000 .^{30}$ The first half of the job was finished. Now university officials faced the onerous task of convincing state legislators to match the contributions from the Rockefeller Foundation and the GEB.

WILLIAM R. BOYD, Walter Jessup, and the other principals had conducted their negotiations with the Rockefeller interests well out of the public eye. They preferred not to have their plan become the subject of public debate until the Rockefeller commitments were sealed. After all, despite an extensive public relations effort, including film clips of a kindly John D. Rockefeller handing out dimes to children, the Rockefeller name was still closely identified with monopoly capitalism. That connection might well spark public controversy in Iowa and might, in fact, have been part of Frederick Gates's objections to the intrusion of the Rockefeller agencies into the public sphere. Moreover, university officials worried that the appearance of eastern interests, Rockefeller or otherwise, commanding the development of medical education in Iowa also had the potential to become an explosive political issue, especially among lowa physicians.

The depressed agricultural economy of the immediate postwar years further clouded prospects for winning matching funds from the Iowa legislature. As William Boyd at one point commented drily to Abraham Flexner, even in the best of circumstances Iowa farmers were "not accustomed to think in seven figures." ${ }^{11}$ State aid for elementary and secondary education amounted to just $\$ 500,000$ annually in the mid-1920s. ${ }^{32}$ Thus, an appropriation of $\$ 450,000$ for construction of a medical campus at the university was a sobering sum, especially for a legislature dominated by farm interests who might also be expected to display considerable anti-Rockefeller sentiment.

30: Flexner to Jessup, 23 November 1922; Flexner to W. H. Gemmill, 24 November 1922; George E. Vincent to Jessup, 7 December 1922, file 1, 192223, Jessup Papers.

31. Flexner, I Remember, 292.

32. Budget Report for the Biennium Beginning July 1, 1925, and Ending June 30, 1927, xxv. 
Finally, Iowans had long displayed considerable ambivalence toward the university itself. Because of its liberal arts emphasis it was often labeled an elitist institution. The university's location in Johnson County, a notoriously "wet" and overwhelmingly Democratic county in a dry, Republican state, was another source of irritation and suspicion, adding a taint of iniquity to the school's elitist reputation. In any event, mothers and fathers in far-flung rural districts of the state had long been reluctant to entrust their children to the university's care.

With those considerations in mind, university officials devised a carefully orchestrated public relations campaign. Concerned first with timing, officials delayed formal announcement of the grants until December 27 in order to avoid having it lost in the pre-Christmas bustle while still capitalizing on the good will of the holiday season. Desiring also to publicize the story as widely and positively as possible, the university sent nearly nine hundred letters to major figures in Iowa politics, business, and education, as well as to a variety of organizations, ranging from the Iowa Bankers Association to the Iowa Federation of Women's Clubs. The university also distributed a lengthy press release that many newspaper editors printed either verbatim or in excerpted form. ${ }^{33}$

Both in the letters and in the press release, university officials emphasized the need for expanded hospital facilities to serve the needs of patient care and medical education. They also celebrated the extraordinary opportunity the grants presented, noting proudly that this was the first time the Rockefeller agencies had bestowed such a gift on a public medical school. "If ever a godsend came to an institution," William Boyd noted for the record, "it is this proffer to the university." Officials were careful to mention Abraham Flexner only in passing, while effusively praising the initiative of Iowans William Boyd, Walter Jessup, and Governor Nathan Kendall, though Kendall had played only a tangential role in the drama. ${ }^{34}$

33. Copies of the press release are in file 1, 1922-23, Jessup Papers.

34. Ibid. 
The university's public relations effort also included a glossy brochure titled "Facts Relative to the $\$ 2,250,000$ Gift to Iowa." The brochure was targeted specifically at members of the Iowa General Assembly. It reiterated the service of the University Hospitals to the state of Iowa, highlighting the hospitals' service to indigent children. It relied more on an emotional appeal than on reasoned argument and the recitation of statistics. Heart-rending "before-and-after" photographs of patients, mostly children whose deformed limbs had been reconstructed in the orthopedic clinics, were meant to soften even the hardest critic. The same photos appeared also in a poster format. ${ }^{35}$

On balance, the initial response to the public relations work was gratifying. In the first days of January 1923 university offices received congratulatory letters and telegrams from individuals and organizations as diverse as the Iowa Pharmaceutical Association, the American Farm Bureau Federation, and the American Legion. Public officials, too, added their voices. U.S. Representative Cyrenus Cole, for example, pointed to "the 5,000 crippled children who have been made whole and happy" by university physicians. "Which of us," Cole went on, "is so poor, not in purse, but in mind and heart" as to oppose acceptance of the Rockefeller gifts? ${ }^{36}$

Favorable editorial comments came from dozens of newspapers across Iowa, including the Waterloo Courier, Sioux City Journal, Clinton Advertiser, Davenport Democrat, Council Bluffs Nonpareil, and Atlantic News. The coverage of the Cedar Rapids Evening Gazette was perhaps typical. Seldom a friend to the university, the Gazette nonetheless gave the story front-page treatment on December 27 and called the Rockefeller funds "a Christmas gift." A follow-up story the next day offered laudatory comments from community leaders, including a declaration from Cedar Rapids Mayor C. D. Huston that the project "should have the interest, sympathy and support of every man and woman in the state." 37

35. Ibid.

36. Ibid.; Marshalltown Times-Republican, 18 February 1923.

37. Cedar Rapids Evening Gazette, 27, 28 December 1922. File 1, 1922-23, Jessup Papers, contains excerpts from dozens of Iowa newspapers. 
But there were rumblings of discontent as well. For example, the Des Moines Register, a politically important-and Republican-newspaper, which was often among the university's most vocal critics, ignored the story altogether in its yearend editions, a silence that spoke loudly in Iowa City. The Farmers Union of Emmet County declared, "We are unalterably opposed to the accepting the [sic] Rockefeller Foundation or any similar donations." The Iowa Homestead shared similar sentiments. ${ }^{38}$ Here were examples of tight-fisted farmers, fearful of a boost in property tax rates and resentful of what they perceived as an "elitist" university, and farmers would hold 64 of the 108 seats in the Iowa House in the Fortieth General Assembly of 1923 .

Troubling, too, was the silence of Iowa's physicians. This silence, like the Register's, was disappointing but not surprising; tensions between the University of Iowa College of Medicine and Iowa's practicing physicians were of long standing. Indeed, the founding of the college in 1870 had provoked a storm of protest from the Iowa State Medical Society, an organization largely controlled by proprietors of the state's private medical schools. The new school, a medical society resolution had charged, represented "a useless expenditure of public money" and entailed the "unnecessary multiplication of medical colleges." 39

Despite that rocky start, by the first decade of the twentieth century most Iowa physicians had at last come to accept the University of Iowa College of Medicine as "their" college. That acceptance came in part because the college's graduates were spread far and wide across the state and in part because the college-with its part-time clinical faculty also drawn from the ranks of Iowa physicians-bore at least an outward resemblance to competing proprietary schools. However, Abraham Flexner had disrupted that hard-won accommodation in 1909. On the one hand, Flexner had exposed fatal weaknesses in medical schools in Keokuk and Des Moines, and by 1914 the University of Iowa College of Medicine was the state's only surviving medical school. On the other hand, Flexner's report had

38. File 1, 1922-23, Jessup Papers.

39. Transactions of the Iowa State Medical Society 1 (1867-1871), 129. 
ended the hold of Iowa physicians on faculty positions in Iowa City, prompting nationwide job searches to relieve the college of the taint of "provincialism." A 1914 report of the Iowa State Medical Society took a dim view of the hiring of "Eastern Graduates as teachers in the University." 40

In addition, many Iowa physicians resented the private practice privileges accorded college faculty, most notably the heads of clinical departments. In 1922, for example, medical college dean Lee W. Dean estimated that Campbell Howard, professor of theory and practice of medicine, enjoyed an annual income of twenty thousand dollars, some fifteen thousand of which came from his private practice conducted in the University Hospitals. ${ }^{41}$ To make matters worse, at least from the perspective of a typical Iowa physician, Howard was a Canadian citizen, and his appointment in 1910 had made him the first in a growing line of "outsiders" to take charge of the college.

The resentment over private practice was both cause and effect of the growing estrangement of academic and practicing physicians in the new world of scientific medicine. University officials maintained that private practice arrangements were essential to attract faculty of Howard's reputation. Still, the use of public facilities for private gain roused biting criticism from the Iowa State Medical Society. In its 1914 report the Iowa State Medical Society charged that College of Medicine faculty were "neglecting their work to attend to private practice." In particular, the report noted with special disapproval that Campbell Howard "has a free office [in the hospital] . . . where he receives his private patients." In short, as one Fort Dodge physician noted at the time, "the medical department of the university is in bad odor with the medical profession of the state." 42

Recognizing that the medical community's silence in January 1923 was a political embarrassment, President Jessup asked Dean Lee W. Dean about the prospects of an endorsement from the Journal of the Iowa State Medical Society. Such an expression

40. "Report on Medical Education in Iowa," Journal of the Iowa State Medical Society 4 (15 July 1915), 81.

41. Dean to Jessup, 6 October 1922, file 1(b), 1922-23, Jessup Papers.

42. "Report on Medical Education in Iowa," 81; J. W. Kime to Thomas H. Macbride, 3 April 1914, file 6, 1914, Macbride Papers. 
of support would be very useful, Dean conceded; however, his chief concern was to see "that an editorial which would not be favorable did not appear" in the organ of the state medical society. ${ }^{43}$

Shortly thereafter, President Jessup received a private message of support from the journal's editor and longtime college supporter, Dr. David S. Fairchild. Fairchild's support encouraged Jessup to pursue the matter further. Jessup wrote to Iowa State Medical Society secretary Tom B. Throckmorton and asked if, on the basis of Fairchild's letter, Throckmorton would provide an editorial endorsement in the journal in February. Through an oversight, Fairchild's letter was not enclosed with Jessup's, and Secretary Throckmorton responded bluntly, "I have no material here from which an editorial could be written." Furthermore, he said, he had little time to write such an editorial. Although President Jessup provided the missing letter from Fairchild by return mail, the exchange with Throckmorton underlined Dean's trepidations about dealing with the medical society. It also apparently spurred Jessup to make a direct appeal to Fairchild, and the February 1923 issue of the Journal of the Iowa State Medical Society contained Fairchild's plea that Iowa physicians forget past divisions "and concentrate on the one great question of developing our Medical University." Clearly David Fairchild, a widely respected elder statesman in Iowa medicine and a fifty-year member of the medical society, was one of the heroes of the hour.

THERE WAS REASON, then, for Jessup, Boyd, and their supporters to suppose that an appropriation of matching funds by the General Assembly was far from a sure thing. In retrospect, however, the political situation was not so bleak as it appeared. The enthusiastic initial public response to news of the Rockefeller largess reflected Iowans' rapidly rising support for the University of Iowa. In the four years prior to 1922 the student body in Iowa City had doubled, reaching some seven

43. Dean to Jessup, 21 January 1923, file 1, 1922-23, Jessup Papers.

44. Throckmorton to Jessup, 26 January 1923; Jessup to Throckmorton, 27 January 1923, file 1, 1922-23, Jessup Papers; Journal of the Iowa State Medical Society 13 (15 February 1923), 61. 
thousand and surpassing enrollment at Iowa State College in Ames, an agricultural college that had long enjoyed far wider public acceptance. Rising enrollments helped the university shed its image of elitism, significantly broadening its constituency among Iowans, and justifying larger appropriations from the Iowa General Assembly. Between 1915 and 1920, for example, annual appropriations for the university rose from $\$ 812,500$ to more than $\$ 2.7$ million. ${ }^{45}$

Moreover, in the late nineteenth and early twentieth centuries a variety of mechanisms had spread the wonders of medical science to a large audience in Iowa as in the rest of America. The combination of an expanding system of public education and mass circulation media had played an important part in that, but the public relations efforts of the medical profession were important as well. For example, since the 1880 s the Iowa State Board of Health had actively publicized the application of the principles of scientific medicine to the control of infectious disease. Likewise, in the twentieth century the near miracles performed at the University Hospitals had bolstered public appreciation of medical science. Thus, in the late nineteenth and early twentieth centuries medical advances such as the isolation of disease-causing organisms, the discovery and application of $X$ rays, the identification of vitamins, and the elaboration of a variety of sophisticated surgical techniques rapidly became part of public culture. At a time when Thomas Edison was a cultural hero, "solutions to disease and death," it often seemed, "were as close as the nearest patent office." 46

45. Iowa State Budget for the Biennium Ending June 30, 1919, p. 21; Budget Report for the Biennium Beginning July 1, 1925, and Ending June 30, 1927, p. 101; Persons, The University of Iowa, 77-83. The Iowa experience was consistent with the nationwide pattern of rising state support for higher education. See Historical Statistics of the United States, Colonial Times to 1970, Part 2 (Washington, D.C., 1975), 1128.

46. See Lee Anderson, "'Headlights Upon Sanitary Medicine': Public Health and Medical Reform in Late Nineteenth-Century Iowa," Journal of the History of Medicine and Allied Sciences 46 (1991), 178-200; Marcel C. LaFollette, Making Science Our Own: Public Images of Science, 1910-1955 (Chicago, 1990); and Nancy Knight, "The New Light: X-Rays and Medical Futurism," in Joseph J. Corn, ed., Imagining Tomorrow: History, Technology, and the American Future (Cambridge, MA, 1986), 67-90. 
Finally, even William Boyd's tight-fisted farmers were unusually buoyant in that winter of 1922-23. After the disastrous slide in farm prices in the immediate postwar years, 1922 had brought a substantial recovery in the prospects of Iowa farmers. For example, spot prices for corn in Chicago markets had risen from a low of forty-eight cents per bushel in January 1922 to seventy-six cents per bushel in December. Although part of that rebound was due to a fall in production in key cropgrowing states, Iowa's farmers had in fact enjoyed bumper crops. Thus, at year's end the future of Iowa agriculture appeared far brighter than anyone could have imagined just twelve months earlier. ${ }^{47}$

Those factors, combined with the mobilization of a network of alumni and other university supporters, help to explain why, contrary to the fears and expectations of many, the course of matching funds legislation through Iowa's Fortieth General Assembly in the first months of 1923 was largely anticlimactic. In the Senate, passage proceeded without a hitch. Introduced as Senate File 453 on February 13, the bill attracted petitions of support from a variety of civic and professional groups, such as the Ottumwa Kiwanis, the Independence American Legion, and chapters of the Daughters of the American Revolution in Des Moines and Sioux City. The groups that supported the appropriation represented a substantial socioeconomic and geographic cross section of Iowa society. Bolstered by such backing, the bill emerged from the Committee on State Educational Institutions on March 17 and from the Appropriations Committee on March 21 before passing the full senate on March 27 by a vote of thirty-three to fifteen. ${ }^{48}$

In the house, support was equally broad, although a small band of opponents sought to stymie passage through a variety of parliamentary maneuvers and harassing amendments. House File 503, introduced on February 15, moved through the Committee on State Educational Institutions without incident, only to stall in the Appropriations Committee chaired by Des Moines Republican A. O. Hauge. Finally, a recall vote by the full

47. See, for example, the Des Moines Register's late December numbers celebrating the agricultural recovery.

48. 1923 Iowa Senate Journal, 471, 861, 966. 
house brought the bill to the floor for consideration on March 30. By sizable margins, the bill's supporters defeated "killing" amendments to include the College of Dentistry in the language of the bill, to earmark auto registration and driver license fees for the necessary appropriation, and to prohibit university employees from accepting "outside pay" for work in the University Hospitals. Then, in order to speed the legislative process and avoid reconsideration in the senate, the house substituted the senate version and gave final approval by an overwhelming margin of eighty-seven to seventeen. ${ }^{49}$

The house vote was, Jessup wired to Flexner, "a great victory." This time the Des Moines Register conceded the story front-page coverage under the headline, "Iowa Assured of $\$ 4,500,000$ Medical Unit." Even before Governor Nathan Kendall signed the bill into law on April 4, a second flood of congratulations poured into university offices. Among those messages were two of special significance. The first was from Abraham Flexner, who had been in a real sense the architect of this "great victory." "We are all delighted" was Flexner's simple message to President Jessup. The second was from Dr. Walter Bierring, who was then president of the State Board of Health but who had been dismissed as head of the Department of Theory and Practice of Medicine at the university in the wake of Flexner's critical 1909 report on the College of Medicine. From Bierring came a gracious message: "You have won a great victory. ... We all rejoice with you." 50

COMPLETION of financing arrangements for the new medical campus at the University of Iowa was indeed cause for rejoicing. Not only was it an improbable conclusion to the salvage effort begun in 1910 by President George E. MacLean and William R. Boyd and redoubled under the administration of Walter A. Jessup; the new hospitals and laboratories also provided the foundation for the remarkable expansion of the

49. 1923 Iowa House Journal, 531, 824, 1262, 1291-96.

50. Jessup to Flexner, 30 March 1923; Flexner to Jessup, 2 April 1923; Bierring to Jessup, 31 March 1923, file 1, 1922-23, Jessup Papers; Des Moines Register, 31 March 1923; Acts and Resolutions of the 40th General Assembly of the State of Iowa, ch. 63, pp. 65-66; Persons, "The Flexner Investigation of the University of Iowa Medical School." 
post-World War II era. Moreover, while this chapter in Iowa medical history was in one sense an intensely local story, it also involved some of the major actors and mirrored much of the experience of American medical science and education in an age of unprecedented scientific advance and institutional growth.

A constellation of factors lay behind the university's success. The determination of George E. MacLean, Walter A. Jessup, Lee W. Dean, and William R. Boyd to build a first-rate medical college at Iowa was an important factor; some critics, in fact, labeled the new medical complex "an architectural memor-

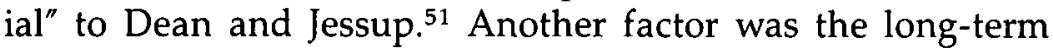
commitment of the Rockefeller Foundation and the General Education Board to underwrite an extensive, if often controversial, reform of American medical education, a commitment significantly broadened in the case of the University of Iowa. Still another important factor was the increasing hold of medical science on the imagination of Iowans-perhaps most surprisingly, on the imagination of Iowa farmers. Contrary to William Boyd's initial doubts, even "farmer members of the house [of representatives] quite solidly supported" the matching funds legislation. ${ }^{52}$

Yet arguably the most important factor in securing the university's new medical campus was the intervention of Abraham Flexner, a development that few could have predicted just ten years earlier. Flexner's special importance lies in the fact that the political and economic constellation of the early 1920s was not a stable one; indeed, it was shattered by the depression of the 1930 s, resulting in drastic reductions in state appropriations for the university and the College of Medicine and inaugurating a period of austerity that extended through the years of World War II. The original piecemeal plan of construction might not have withstood the test of those fifteen years of budgetary stringency. Thanks to Flexner, it did not have to. Therefore, the University of Iowa's new medical complex is most properly seen as a monument to Abraham Flexner.

51. Fred Moore to Jessup, 5 May 1927, file 73, 1926-27, Jessup Papers.

52. Des Moines Register, 30 March 1923. 
Copyright of Annals of Iowa is the property of State of Iowa, by \& through the State Historical Society of Iowa and its content may not be copied or emailed to multiple sites or posted to a listserv without the copyright holder's express written permission. However, users may print, download, or email articles for individual use. 